Louisiana State University

LSU Digital Commons

Faculty Publications

Department of Geology and Geophysics

$1-1-2014$

\title{
Primitive layered gabbros from fast-spreading lower oceanic crust
}

\author{
Kathryn M. Gillis \\ University of Victoria \\ Jonathan E. Snow \\ University of Houston \\ Adam Klaus \\ Texas A\&M University \\ Natsue Abe \\ Japan Agency for Marine-Earth Science and Technology \\ Álden B. Adrião \\ Universidade Federal do Rio Grande do Sul
}

See next page for additional authors

Follow this and additional works at: https://digitalcommons.Isu.edu/geo_pubs

\section{Recommended Citation}

Gillis, K., Snow, J., Klaus, A., Abe, N., Adrião, Á., Akizawa, N., Ceuleneer, G., Cheadle, M., Faak, K., Falloon, T., Friedman, S., Godard, M., Guerin, G., Harigane, Y., Horst, A., Hoshide, T., Ildefonse, B., Jean, M., John, B., Koepke, J., MacHi, S., Maeda, J., Marks, N., McCaig, A., Meyer, R., Morris, A., Nozaka, T., Python, M., Saha, A., \& Wintsch, R. (2014). Primitive layered gabbros from fast-spreading lower oceanic crust. Nature, 505 (7482), 204-207. https://doi.org/10.1038/nature12778

This Article is brought to you for free and open access by the Department of Geology and Geophysics at LSU Digital Commons. It has been accepted for inclusion in Faculty Publications by an authorized administrator of LSU Digital Commons. For more information, please contact ir@lsu.edu. 


\section{Authors}

Kathryn M. Gillis, Jonathan E. Snow, Adam Klaus, Natsue Abe, Álden B. Adrião, Norikatsu Akizawa, Georges Ceuleneer, Michael J. Cheadle, Kathrin Faak, Trevor J. Falloon, Sarah A. Friedman, Marguerite Godard, Gilles Guerin, Yumiko Harigane, Andrew J. Horst, Takashi Hoshide, Benoit Ildefonse, Marlon M. Jean, Barbara E. John, Juergen Koepke, Sumiaki MacHi, Jinichiro Maeda, Naomi E. Marks, Andrew M. McCaig, Romain Meyer, Antony Morris, Toshio Nozaka, Marie Python, Abhishek Saha, and Robert P. Wintsch 


\section{UNIVERSITY OF LEEDS}

This is a repository copy of Primitive layered gabbros from fast-spreading lower oceanic crust.

White Rose Research Online URL for this paper:

http://eprints.whiterose.ac.uk/80357/

Version: Accepted Version

\section{Article:}

Gillis, KM, Faak, K, Snow, JE et al. (27 more authors) (2014) Primitive layered gabbros from fast-spreading lower oceanic crust. Nature, 505 (7482). pp. 204-207. ISSN 0028-0836

https://doi.org/10.1038/nature12778

\section{Reuse}

Items deposited in White Rose Research Online are protected by copyright, with all rights reserved unless indicated otherwise. They may be downloaded and/or printed for private study, or other acts as permitted by national copyright laws. The publisher or other rights holders may allow further reproduction and re-use of the full text version. This is indicated by the licence information on the White Rose Research Online record for the item.

\section{Takedown}

If you consider content in White Rose Research Online to be in breach of UK law, please notify us by emailing eprints@whiterose.ac.uk including the URL of the record and the reason for the withdrawal request. 


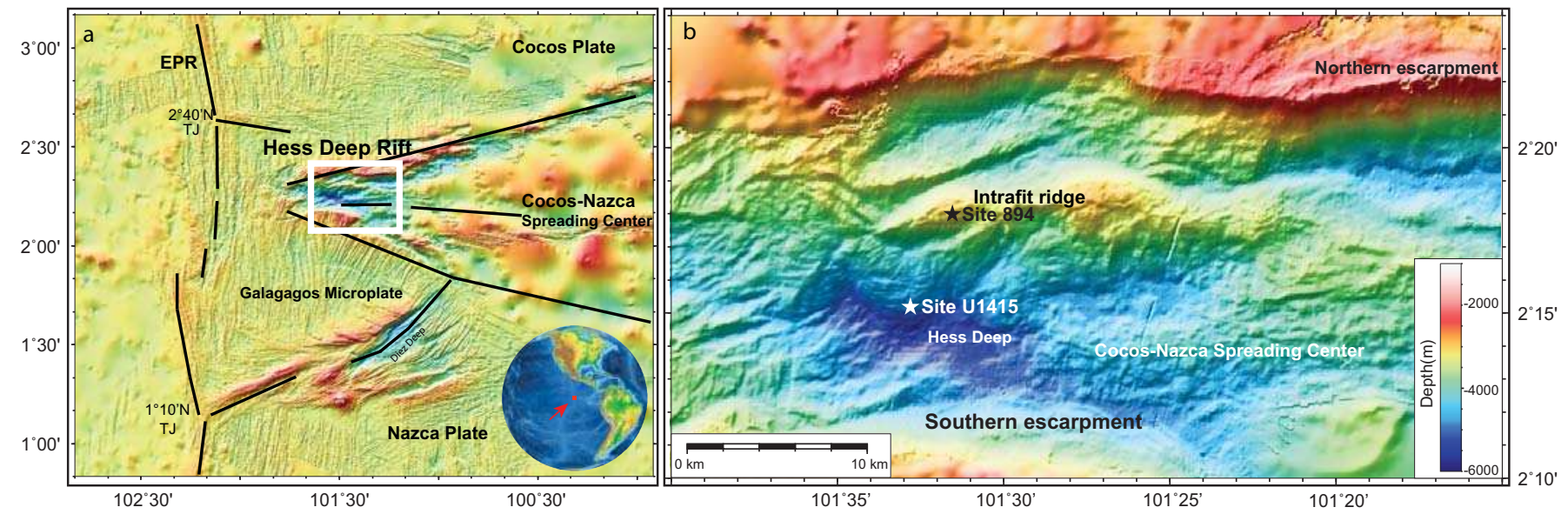

Figure 1 Gillis et al 


\section{Primitive Layered Gabbros from Fast-Spreading Lower Oceanic Crust}

Kathryn M. Gillis ${ }^{1}$, Jonathan E. Snow ${ }^{2}$, Adam Klaus ${ }^{3}$, Natsue Abe ${ }^{4}$, Álden B. Adrião, Norikatsu Akizawa ${ }^{6}$, Georges Ceuleneer ${ }^{7}$, Michael J. Cheadle ${ }^{8}$, Kathrin Faak ${ }^{1,9}$, Trevor J. Falloon $^{10}$, Sarah A. Friedman ${ }^{11}$, Marguerite Godard ${ }^{12}$, Gilles Guerin ${ }^{13}$, Yumiko Harigane $^{14}$, Andrew J. Horst ${ }^{15}$, Takashi Hoshide ${ }^{16}$, Benoit Ildefonse ${ }^{12}$, Marlon M. Jean ${ }^{17}$, Barbara E. John ${ }^{8}$, Juergen Koepke ${ }^{18}$, Sumiaki Machi ${ }^{6}$, Jinichiro Maeda ${ }^{19}$, Naomi E. Marks $^{20}$, Andrew M. McCaig ${ }^{21}$, Romain Meyer ${ }^{22}$, Antony Morris ${ }^{23}$, Toshio Nozaka ${ }^{24}$, Marie Python ${ }^{19}$, Abhishek Saha ${ }^{25}$, Robert P. Wintsch ${ }^{26}$.

Revised manuscript submitted to Nature 8 October 2013

${ }^{1}$ School of Earth and Ocean Sciences, University of Victoria, PO Box 1700 Station CSC, Victoria, BC, V8W 3V6, Canada; ${ }^{2}$ Earth \& Atmospheric Sciences, University of Houston, 312 Science and Research Building 1, Houston TX 77204-5007, USA; ${ }^{3}$ United States Implementing Organization, Integrated Ocean Drilling Program, Texas A\&M University, 1000 Discovery Drive, College Station TX 77845, USA; ${ }^{4}$ Institute for Research on Earth Evolution, (IFREE), Japan Agency for Marine-Earth Science and Technology (JAMSTEC), 2-15 Natsushima-cho, Yokosuka 237-0061, Japan; ${ }^{5}$ IGEO (Geology Institute), Rio Grande do Sul Federal University (UFRGS), Av. Bento Gonçalves, 9500 Bloco I Prédio, 43113 Sala 207, Alegre/RS, Brazil; ${ }^{6}$ Department of Earth Sciences, Kanazawa University, Kakuma-machi, Kanazawa Ishikawa 920-1192, Japan; ${ }^{7}$ Observatoire Midi-Pyrénées (UMS 831), CNRS, Université Paul Sabatier, 14 Avenue Edouard Belin, Toulouse Cedex 31400, France; ${ }^{8}$ Department of Geology and Geophysics, University of Wyoming, 1000 University Avenue, Department 3006, Laramie WY 82071, USA; ${ }^{9}$ Institut fuer Geologie, Mineralogie, and Geophysik, RuhrUniversitaet Bochum, Universitaetsstr.150, 44780 Bochum, Germany; ${ }^{10}$ Institute for Marine and Antarctic Studies and School of Earth Sciences, University of Tasmania, Hobart, Tasmania 7001, Australia; ${ }^{11}$ Department of Geology, Southern Illinois University at Carbondale, Carbondale IL 62901, USA; ${ }^{12}$ Géosciences Montpellier, Université Montpellier 2, CNRS UMR5243, CC 60, 34095 Montpellier cedex 5, France;

${ }^{13}$ Borehole Research Group, Lamont-Doherty Earth Observatory of Columbia, University, PO Box 1000, 61 Route 9W, Palisades NY 10964, USA; ${ }^{14}$ Institute of Geology and Geoinformation, Geological Survey of Japan, National Institute of Advanced Industrial Science and Technology, AIST Tsukuba Central 7, 1-1-1 Higashi, Tsukuba Ibaraki 305-8567, Japan; ${ }^{15}$ Department of Geology, Oberlin College, Oberlin $\mathrm{OH} 44074$, USA; ${ }^{16}$ Graduate School of Science, Tohoku University, Aoba-ku, Sendai 980-8578, Japan; ${ }^{17}$ Department of Geology and Environmental, Geosciences, Northern Illinois University, Davis Hall 312, Normal Road, DeKalb IL 60115, USA; ${ }^{18}$ Institut für Mineralogie, University of Hannover, Callinstrasse 3, Hannover 30167, Germany;

${ }^{19}$ Department of Natural History Sciences, Hokkaido University, North 10, West 8, Kitaku, Sapporo Hokkaido 060-0810, Japan; ${ }^{20}$ Chemistry and Material Sciences Department, Lawrence Livermore National Laboratory, PO Box 808, L-231, Livermore CA 94551, USA; ${ }^{21}$ School of Earth and Environment, University of Leeds, Leeds LS2 9JT, UK; ${ }^{22}$ Centre for Geobiology and Department of Earth Science, University of Bergen, Allegaten 41, Bergen 5007, Norway; ${ }^{23}$ School of Geography, Earth and Environmental Sciences, Plymouth University, Drake Circus, Plymouth PL4 8AA, United Kingdom; ${ }^{24}$ Department 
of Earth Sciences, Okayama University, 3-1-1 Tsushima-naka, Okayama 700-8530, Japan; ${ }^{25}$ Department of Geology, University of Calcutta, 35, Ballygunge Circular Road, Kolkata 700 019, India; ${ }^{26}$ Dept. of Geological Sciences, Indiana University, 1001 East 10th Street, Bloomington IN 47405, USA.

Three-quarters of the ocean crust formed at fast-spreading ridges is composed of plutonic rocks whose mineral assemblages, textures and compositions record the history of melt transport and crystallization between the mantle and the seafloor. Despite the significance of these rocks, sampling them in situ is extremely challenging due to the overlying dikes and lavas. This means that our models for understanding the formation of the lower crust are based largely on geophysical studies $^{1}$ and ancient analogues (ophiolites) ${ }^{2-5}$ that did not form at typical mid-ocean ridges. We report here the first significant cored intervals of primitive modally layered gabbroic rocks from the lower plutonic crust formed at a fast-spreading ridge, sampled by the Integrated Ocean Drilling Program (IODP) at the Hess Deep Rift (HDR). Spectacular cm-scale modally layered rocks, some of which have a strong layering parallel foliation, confirm a long held paradigm that such rocks are a key constituent of the lower ocean crust formed at fast-spreading ridges ${ }^{3,6}$. Geochemical analysis of these primitive lower plutonics, in combination with previous geochemical data for shallow-level plutonics, sheeted dikes and lavas, provides the most completely constrained estimate of the bulk composition of fastspreading oceanic crust to date. Simple crystallization models using this bulk crustal composition as the parental melt accurately predict the bulk composition of both the lavas and plutonics. However, the recovered plutonic rocks show early crystallization of orthopyroxene, which is not predicted by current models of melt extraction from the mantle ${ }^{7}$ and mid-ocean ridge basalt (MORB) differentiation ${ }^{8,9}$. 


\section{This observation is most simply explained if compositionally diverse melts are extracted from the mantle and partially crystallize prior to mixing to produce the more homogeneous magmas that erupt.}

The gabbroic rocks that make up the lowermost oceanic crust formed at fastspreading ridges, such as the East Pacific Rise (EPR), have long been assumed to be modally layered and primitive in composition ${ }^{4,6,10,11}$. Igneous layering, and a layeringparallel foliation, are nearly ubiquitous in the lower plutonic sections of many ophiolites $^{3,5,10}$ and explaining the formation of these layered rocks has become central to models for the accretion of the plutonic crust at fast-spreading ridges ${ }^{2,4,5}$. Accretion models have evolved from layers accumulating along the floors of large magma bodies 3,6 to layers developing in sill-like magma bodies focused at the top of the crystal mush within axial magma chambers and/or distributed throughout the crustal mush zone $e^{2,4,5}$. Until now, however, no significant cored intervals of layered gabbros have been recovered from the lower plutonic section at a modern fast-spreading ridge.

IODP Expedition 345 was conceived as a test of whether modern fast-spread crust shows layering similar to many ophiolites and to test models for the transport of parental melts into the crust and differentiation of these melts within the crust. In order to sample the generally inaccessible lower plutonic crust, the expedition took advantage of the tectonic window at the HDR in the equatorial Pacific ${ }^{11,12}$ (Fig. 1). This site is unique as it is the only place where the lower- to upper-crust have been extensively sampled by submersible or $\mathrm{ROV}^{11-14}$ and drilling (ODP Leg 147) ${ }^{15}$, and previous studies of known seafloor exposures of lower plutonic rocks have suggested that layering exists ${ }^{11,12}$. At Site U1415, primitive olivine gabbros and troctolites were recovered at one 35-m-deep hole 
(U1415I) and two 110-m-deep holes (U1415J, U1415P), located within $100 \mathrm{~m}$ of each other (Extended Data Fig. 1). Sampling of primitive layered gabbro and troctolite series at Site U1415 thus provides the final part of the most complete composite section of fastspreading East Pacific Rise crust to date.

Simple modally layered and irregular banded rocks, collectively called the layered gabbro series, were recovered in all three drill holes, comprising $>50 \%$ of the core. The layered gabbro series in Holes U1415I and U1415J show simple modal layering, with or without concurrent grain size variations, on a scale of centimeters to decimeters (Fig. 2a, Extended Data Fig. 2). Layers include troctolite, olivine-gabbro, gabbro and gabbronorite with local variations in texture (e.g., clinopyroxene oikocryst-bearing). Layering is reminiscent of so-called dynamic layering resulting from magmatic flow ${ }^{16}$ commonly found in layered mafic intrusions and some ophiolites. A layering parallel foliation exists throughout these rocks that is commonly strong (Fig. 2c) and locally anastomoses around large oikocrysts. In contrast, the layered gabbro series in Hole U1415P displays irregular banding that is identified by modal and grain size variations, with all of the same lithologies present in the simple layers of Holes U1415 I and U1415J, but also includes rare anorthositic bands (Fig. 2b). Grain size variation is much more extreme and heterogeneous than the simple layers, bands can be discontinuous, and one lithology can enclose another. Additionally, the boundaries between bands are generally less planar than the simple layers, show abrupt changes in mineralogy leading to asymmetric distributions of distinct leucocratic and melanocratic bands (Fig. 2b), and mineral foliations are weak or absent. This banding is reminiscent of non-dynamic layering in layered mafic intrusions that is the result of varying rates of nucleation and growth, and 
post-cumulus processes ${ }^{17,18}$. The troctolite series at the base of Holes U1415J and U1415P contain melanocratic to leucocratic troctolite with little or no layering or banding and a weak to moderate foliation (Extended Data Fig. 1). Evolved lithologies such as FeTi-oxide gabbros and felsic veins, prevalent in the upper gabbros ${ }^{15}$, are strikingly absent throughout the cores indicating that evolved residual melt was efficiently extracted from the lower plutonic crust. Also absent are mantle rocks, suggesting the recovered lithologies are not part of the mantle transition zone.

The foliation and layering in the layered gabbro series provide important constraints on the processes of crustal accretion. There is little sub-solidus crystal plastic deformation meaning that the foliations were formed early while the rocks were still partially molten. In addition, olivine commonly exhibits skeletal morphologies, which limits the amount of grain-scale strain that some of the rocks may have experienced at low melt fractions. The abundance of layering in the material recovered from Site U1415, along with the absence of intermixed evolved lithologies, distinguishes the HDR lower gabbroic crust from crustal sections recovered from slow-spreading ridges (see, for example, ref. 19). This supports models that invoke a strong spreading rate/thermal control on magma chamber processes at mid-ocean ridges ${ }^{20}$. Furthermore, the occurrence of layering that resembles both dynamic ${ }^{16}$ and non-dynamic ${ }^{17}$ layering in layered mafic intrusions suggests multiple mechanisms of crustal accretion and melt differentiation. This variation in style of layering and banding, and the diversity of lithologies, differs from the MORB-like, southern portions of the Oman ophiolite that has been used as a fast-spreading ridge analogue $\mathrm{e}^{3,5}$. The primary difference is that simple modal layering dominates and irregular banding is very rare in this region of $\mathrm{Oman}^{3}$. 
The Site U1415 cores are much more primitive (high MgO, high Mg\#) than previously recovered samples of the overlying upper gabbros (Fig. 3). These new samples allow estimation of the bulk composition of fast-spread ocean crust because the thickness of the crust and its component parts can be estimated along with uncertainties from field relationships determined from four previous submersible surveys ${ }^{11,13,14}$ and ODP Leg 147 drilling ${ }^{15}$ (details in Methods). The relative proportions of the upper crust (lavas and dikes: $22.5 \pm 4.5 \%$ of the crust) and shallow-level gabbros (32.5 $\pm 7.5 \%$ of the plutonics) constrain the plausible fraction of deeper gabbros. For these calculations we use the mean compositions of the upper crust (lavas and sheeted dikes) from the northern escarpment, the shallow-level gabbros from the northern escarpment and ODP Site 894 and the lower gabbros from IODP Site U1415 (see Fig. $1 \mathrm{~b}$ for locations; Extended Data Table 1).

The calculated bulk composition of the HDR crust (Extended Data Table 1) contains $12.1 \pm 1.0 \mathrm{wt} \% \mathrm{MgO}, 7.7 \pm 0.4 \mathrm{wt} \% \mathrm{FeO}^{\text {Total }}$ with an $\mathrm{Mg} \#$ of $74 \pm 1$, falling at the Mg-rich end of the range of experimentally determined parental melts for mid-ocean ridge basalts ${ }^{21}$. The calculated liquidus temperature is $\sim 1290-1300^{\circ} \mathrm{C}$ and fractional crystallization models follow the expected mid-ocean ridge basalt (MORB) sequence of olivine $\left(\sim \mathrm{Fo}_{90-91}\right)$ followed by plagioclase $\left(\sim \mathrm{An}_{84-87}\right)$ then clinopyroxene $\left(\sim \mathrm{Mg} \#_{86-88}\right)$ with orthopyroxene $\left(\sim \mathrm{Mg} \#_{75-82}\right)$ saturation at $\sim 1165-1180^{\circ} \mathrm{C}^{22,23}$ with $46-35 \%$ melt remaining ${ }^{22,23}$ (Fig. 3; details in Methods). The first olivine to be produced in these models has a similar Fo-content to the olivine in dunites and harzburgites recovered from Hess Deep by previous drilling $\left(\mathrm{Fo}_{89.4-91.3^{24,25}}\right)$; this is consistent with the bulk-crustal composition being representative of a primary mantle melt extracted either directly from the harzburgites or through dunite channels ${ }^{7,24}$. 
An unexpected finding is that cumulus orthopyroxene commonly occurs in primitive (bulk-rock $\mathrm{Mg}_{80-85}$ ) plutonic rocks from the deep portion of the crust at the HDR (Fig. 2d). Orthopyroxene is a common minor cumulus and early inter-cumulus phase $(<5 \%)$ in olivine gabbro, gabbro, gabbronorite and troctolite in the layered gabbro series. In contrast, the virtual absence of orthopyroxene as a phenocryst in MORB globally (including HDR), as well as experimental studies of MORB differentiation (see, for example, ref. 8) and modeling of the differentiation with our bulk-crustal composition (Fig. 3) all indicate that orthopyroxene should not be a liquidus phase until $>50 \%$ crystallization has occurred with a substantial interval of clinopyroxene crystallization preceding orthopyroxene saturation. Such late stage orthopyroxene is commonly found in more evolved gabbros, including the shallow-level gabbros from the $\mathrm{HDR}^{15}$.

Orthopyroxene is ubiquitous in the upper mantle where its coexistence with olivine buffers the silica activity in primary mantle melts. The expected late crystallization of orthopyroxene in MORB is due to the generation of MORB via polybaric, near-fractional melting ${ }^{26,27}$, with an average melting pressure of about 10 kbars $^{27}$. Decompression of melts aggregated from throughout the melting column leads to an expansion of the olivine stability field, and shrinking of the orthopyroxene stability field, leaving the low-pressure melt far from orthopyroxene saturation ${ }^{28}$. Although several processes could explain the occurrence of orthopyroxene in the deep primitive gabbros at the HDR, most seem unlikely. For example, the parental magmas could be more oxidized than typical MORB. This would lead to less of the Fe in the melt being divalent and hence available to partition into mafic phases ${ }^{29}$ and could also lead to early oxide saturation driving an increase in silica activity, both of which could lead to early 
orthopyroxene saturation. However, this model is difficult to reconcile with either the normal differentiation trends observed in the overlying lavas and dikes, including Feenrichment trends ${ }^{30}$, or the virtual absence of FeTi-oxides (typically $\leq 0.1$ modal \%) in the Site U1415 rocks. Another possibility is that orthopyroxene saturation is influenced by the addition and removal of $\mathrm{H}_{2} \mathrm{O}$ from the system ${ }^{31}$. The low water content of primitive $\mathrm{MORB}^{32}$ and the observation that the Site U1415 cumulates contain almost no magmatic amphibole, suggest very limited $\mathrm{H}_{2} \mathrm{O}$ in the system making this an unlikely scenario. The most reasonable explanation is that orthopyroxene was precipitated from a primitive melt that had undergone little decompression since being in (major element) equilibrium with shallow mantle orthopyroxene. This can be explained if this melt either was generated by shallow mantle melting, or re-equilibrated with the shallow mantle as it was transported through it, and crystallized within the crust without first mixing with aggregated MORB melts in the crust ${ }^{33}$. Partial re-equilibration of melt during shallow mantle transport is supported by the relatively high $\mathrm{Sr}$ content of the primitive cumulates which suggests that their parental melt was not depleted in incompatible elements. If this model is correct, it indicates that diverse melt compositions feed the crust, and the lower crust acts as an efficient filter for mixing these prior to the eruption of their homogenized and differentiated products.

Overall, our findings demonstrate that although the bulk oceanic crust at the HDR has a similar composition to that which has been predicted for parental MORB there is a greater diversity in parental melts added into the crust than expected. Partial crystallization of these diverse melts occurs prior to mixing, something that is not considered in models of MORB differentiation. However, such melts are not erupted 
indicating that melt transport through the lower crust acts as an efficient mechanism to homogenize the Moho-crossing melts. The heterogeneity in the lithologies, bulk compositions, layering types and foliation strength observed within the Site U1415 core suggests complex melt differentiation and crustal accretion processes in the lower crust at fast-spreading ridges.

\section{Methods Summary}

The bulk composition of the EPR crust exposed at the HDR and its uncertainty were calculated using new and published compositions and relative mass fractions of the main crustal lithologies: lavas and dikes, shallow-level gabbros, and deep-level gabbros (Extended Data Table 1). The mass fractions of the crustal lithologies and their

uncertainties are derived from field observations ${ }^{11-14}$. A series of models ${ }^{22,23}$ were run to investigate whether differentiation of a parental melt with the composition of the bulk crust would produce cumulates and residual melts of similar composition to the observed plutonics and upper crustal rocks at the HDR. A fuller description is given in Methods.

Full Methods and any associated references are available in the online version of the paper. 


\section{References}

1 Detrick, R.S. et al., Multichannel seismic imaging of a crustal magma chamber along the East Pacific Rise. Nature 326, 35-41 (1987).

2 Kelemen, P.B. \& Aharanov, E., Periodic formation of magma fractures and generation of layered gabbros in the lower crust beneath oceanic spreading ridges in Faulting and Magmatsim at Mid-Ocean Ridges, edited by W.R. Buck, P.T. Delaney, J.A. Karson, \& Y. Lagrabrielle, pp. 267-289 (Geophysical Monograph Series 106, Washington, 1998). Pallister, J.S. \& Hopson, C.A., Samail ophiolite plutonic suite: field relations, phase variation, cryptic variation and layering, and a model of a spreading ridge magma chamber. J. Geophys. Res. 86, 2593-2644 (1981).

Quick, J.E. \& Denlinger, R.P., Ductile deformation and the origin of layered gabbro in ophiolites. J. Geophys. Res. 98, 14015-14027 (1993).

Boudier, F., Nicolas, A., \& Ildefonse, B., Magma chambers in the Oman Ophiolite: fed from the top and the bottom. Earth Planet. Sci. Lett. 144, 239-250 (1996).

Cann, J.R., A model for oceanic crustal structure developed. Geophys. J. R. Astr. Soc. 39, 169-187 (1974). Kelemen, P.B., Shimizu, N., \& Salters, V.J.M., Extraction of mid-ocean-ridge basalt from the upwelling mantle by focused flow of melt in dunite channels. Nature 375, 747-753 (1995).

Grove, T.L., Kinzler, R.J., \& Bryan, W.B., Fractionation of Mid-Ocean Ridge Basalt (MORB) in Mantle Flow and Melt Generation at Mid-Ocean Ridges, 
edited by J. Phipps Morgan, D.K. Blackman, \& J.M. Sinton, pp. 281-311

(Geophysical Monograph Series 71, 1992).

9

10

O’Neill, H.S.C. \& Jenner, F.E., The global pattern of trace-element distributions in ocean floor basalts. Nature 491, 698-704 (2012).

Nicolas, A., Boudier, F., \& Ceuleneer, G., Mantle flow patterns and magma chambers at ocean ridges - evidence from the Oman ophiolite. Mar. Geophys. Res. 9, 293-310 (1988).

Francheteau, J. et al., 1 Ma East Pacific Rise oceanic crust and uppermost mantle exposed by rifting in Hess Deep (equatorial Pacific Ocean). Earth Planet. Sci. Lett. 101, 281-295 (1990).

Hékinian, R., Bideau, D., Francheteau, J., Lonsdale, P., \& Blum, N., Petrology of the East Pacific Rise crust and upper mantle exposed in the Hess Deep (eastern equatorial Pacific). J. Geophys. Res. 98, 8069-8094 (1993).

Karson, J.A. et al., Structure of uppermost fast-spread oceanic crust exposed at the Hess Deep Rift: Implications for subaxial processes at the East Pacific Rise. Geochem., Geophys., Geosys. 3, $2001 \mathrm{GC} 000155$ (2002). Lissenberg, C.J., MacLeod, C.J., Howard, K.A., \& Godard, M., Pervasive reactive melt migration through fast-spreading lower oceanic crust (Hess Deep, equatorial Pacific Ocean). Earth Planet. Sci. Lett. 361, 436-447 (2013).

15 Gillis, K.M., Mével, C., \& Allan, J., eds., Proc. ODP, Init. Repts., Vol. 147, (Ocean Drilling Program, College Station, TX, 1993). McBirney, A.R. \& Nicolas, A., The Skaergaard Layered Series. Part II. Magmatic flow and dynamic layering. J. Petrol. 38, 569-580 (1997). 
Boudreau, A.E. \& McBirney, A.R., The Skaergaard Layered Series. Part III. Nondynamic layering. Jour. Petrol. 38 (8), 1003-1020 (1997). Naslund, H.R. \& McBirney, A.R., Mechaisms of formation of igenous layering in Layered Igneous Intrusions, edited by R.G. Cawthron, pp. 1-43 (Developments in Petrology 15, Elsevier, Amsterdam, 1996).

Blackman, D.K. et al., Drilling constraints on lithospheric accretion and evolution at Atlantis Massif, Mid-Atlantic Ridge 30 degrees N. J. Geophys. Res. 116, 25 (2011). Henstock, T.J., Woods, A.W., \& White, R.S., The accretion of oceanic crust by episodic sill intrusion. J. Geophys. Res. 98 (B3), 4143-4161 (1993).

21 Kinzler, R.J. \& Grove, T.L., Primary magmas of mid-ocean ridge basalts. 2. Applications. J. Geophys. Res. 97 (B5), 6907-6926 (1992). Ghiorso, M.S. \& Sack, R.O., Chemical mass transfer in magmatic processes IV. A revised and internally consistent thermodynamic model for the interpolations of liquid-solid equilibria in magmatic systems at elevated temperatures and pressures. Contrib. Mineral. Petrol. 119, 197-212 (1995). Danyushevsky, L.V. \& Plechov, P., Petrolog3: Integrated software for modeling crystallization processes. Geochem. Geophys. Geosys. 12, 32 (2011). Dick, H.J.B. \& Natland, J.H., Late-stage melt evolution and transport in the shallow mantle beneath the East Pacific Rise in Proc. ODP, Sci. Results 147, edited by C. Mével, K.M. Gillis, J.F. Allan, \& P.S. Meyer, pp. 103-134 (Ocean Drilling Program, College Station, TX, 1996). 
Arai, S. \& Matsukage, K., Petrology of the gabbro-troctolite-peridotite complex from Hess Deep, equatorial Pacific: Implications for mantle-melt interaction within the oceanic lithosphere in Proc. ODP, Sci. Results 147, edited by C. Mével, K.M. Gillis, J. Allan, \& P. Meyer, pp. 135-155 (Ocean Drilling Program, College Station, TX, 1996). mantle: An ion microprobe study of diopsides in abyssal peridotites. J. Geophys. Res. 95, 2661-2678 (1990). Langmuir, C.H., Klein, E.M., \& Plank, T., Petrological systematics of mid-ocean ridge basalts: constraints on melt generation beneath ocean ridges in Mantle Flow and Melt Generation at Mid-ocean Ridges, edited by J. Phipps Morgan, G.K. Blackman, \& J.M. Sinton, pp. 183-280 (Geophysical Monograph Series 71, Washington, 1992). O'Hara, M.J., Are ocean floor basalts primary magma? Nature 220, 683-685 (1968). stability and olivine pyroxene liquid equilibria at 1-Atm in natural basaltic and andesitic liquids. Contrib. Mineral. Petrol. 103 (3), 287-305 (1989). Stewart, M.A., Klein, E.M., \& Karson, J., Geochemistry of dikes and lavas from the north wall of the Hess Deep Rift: insights into the four-dimensional character of crustal construction at fast-spreading mid-ocean ridges. J. Geophys. Res. 107, 2238, doi: 2210.1029/2001JB000545 (2002). 
31 Berndt, J., Koepke, J., \& Holtz, F., An experimental investigation of the influence of water and oxygen fugacity on differentiation of MORB at $200 \mathrm{MPa}$. J. Petrol. $46(1), 135-167(2005)$. in primitive mid-ocean-ridge basalt and the volatile content of Earth's upper mantle. Nature 419, 451-446 (2002).

33 Coogan, L.A., Gillis, K.M., MacLeod, C.J., Thompson, G.M., \& Hékinian, R., Petrology and geochemistry of the lower ocean crust formed at the East Pacific Rise and exposed at Hess Deep: A synthesis and new results. Geochem., Geophys., Geosys. 10.1029/2001/GC000230 (2002). 
Acknowledgements. This research used samples and data provided by the Integrated Ocean Drilling Program (IODP). We thank the USIO staff and Siem Offshore crew for their tenacity in recovering hard rock core in an unsedimented environment at $>4850$ meters water depth, and for their invaluable assistance during the expedition. We gratefully acknowledge the contributions of the drilling proposal proponents, and the leaders (C. MacLeod and D. Teagle) and participants of the RRS James Cook site survey cruise (JC21) in making IODP Expedition 345 possible. We thank E. Klein and H. Dick their constructive reviews.

Author contributions. All authors were shipboard participants on IODP Expedition 345, contributed to the shipboard data collection, and discussed the results and their implications. KMG wrote the first draft of the manuscript, KMG and JES were co-chief scientists on the expedition, and AK was the staff scientist.

Author information. Reprints and permissions information is available at www.nature.com/reprints. The authors declare no competing financial interests. Readers are welcome to comment on the online version of the paper. Correspondence and requests for materials should be addressed to K.M.G. (kgillis@uvic.ca). 


\section{Figure Captions.}

\section{Figure 1. Tectonic setting of the Hess Deep Rift and location of IODP Site U1415.}

The Hess Deep Rift (HDR) formed by deep lithospheric extension in front of the westward propagating Cocos-Nazca spreading center exposing oceanic crust that formed at the fast-spreading (130 mm/y) East Pacific Rise. Upper crustal lavas and dikes are exposed along the northern and southern escarpments, shallow-level gabbros along the northern escarpment and the western intrarift ridge, and lower level gabbros along the southern slope of the intrarift ridge $\mathrm{e}^{11-14}$. a, Map of the Galapagos triple junction in the eastern equatorial Pacific Ocean showing major tectonic boundaries. EPR = East Pacific Rise, $\mathrm{TJ}=$ triple junction. White box indicates location of the map in b. b, Regional bathymetric map of the HDR showing key morphological features and locations of IODP Site U1415 and ODP

Site 894. Maps show bathymetry derived from satellite altimetry data and archived multibeam bathymetry data available from the Global Multi-Resolution Topography Data Portal at Lamont-Doherty Earth Observatory.

Figure 2. Typical gabbroic rocks at Site U1415. a, Simple centimeter-scale modal layers of alternating lithology (labeled to right of core); layer boundaries are sharp and planar and a layering parallel foliation is seen throughout (Hole U1415I, section 4R-1, 47-115 cm); additional examples are given in Extended Data Fig. 2. b, Orthopyroxene-bearing olivine gabbro showing irregular, steeply dipping leucocratic and melanocratic bands that range from distinct to weak. Banding is defined by modal, grain-size and textural variations. Also of note is an 
orthopyroxene-rich band (Hole U1415P, section 8R-1, 86-144 cm). c,

Photomicrograph of a troctolite in the layered gabbro series showing a strong magmatic foliation indicated by the red arrow, cross-polarized light (sample U1415I, section 4R-2, 0-4 cm, piece 2). d, Photomicrograph showing cumulus orthopyroxene in an orthopyroxene-bearing olivine gabbro, cross-polarized light (sample U1415P, section 4G-1, 5-7 cm, piece 2). Abbreviations: $\mathrm{Ol} \mathrm{G}=$ olivine gabbro, $\mathrm{Tr}=$ troctolite, $\mathrm{GN}=$ gabbronorite, $\mathrm{Ol} \mathrm{GN}=$ olivine-bearing gabbronorite, Opx $\mathrm{Ol} \mathrm{G}=$ orthopyroxene-bearing olivine gabbro, $\mathrm{Ol}=$ olivine, $\mathrm{Opx}=$ orthopyroxene, $\mathrm{Pl}=$ plagioclase.

\section{Figure 3. Variations in whole-rock $\mathrm{CaO}$ (a) and $\mathrm{Al}_{2} \mathrm{O}_{3}$ (b) with $\mathrm{MgO}$ for different} parts of the crust at the HDR. The lower plutonics recovered from Site U1415 are much more primitive than the shallow plutonics. The compositions of the lower gabbro cumulates and lavas and dikes can be broadly explained using a simple fractional crystallization model (grey arrows) of the bulk-crustal composition but the shallow gabbros clearly contain substantial trapped melt in the bulk composition (i.e. are mixtures of cumulate and melt compositions). The uncertainties for the bulk crust and plutonic section compositions lie within the size of their symbols (Extended Data Table 1). Fractional crystallization trends (showing instantaneous compositions) for the melt (thick solid light-grey arrow) and cumulates (thick dashed dark-grey arrow) calculated using output of the PETROLOG program ${ }^{23}$ schematically encompass the range of models considered (Methods). The first appearance of each mineral modeled is shown for the cumulate 
crystallization trend: olivine is the liquidus phase, plagioclase appears after $\sim 7 \%$ crystallization, clinopyroxene appears after $\sim 32$ to $35 \%$, and orthopyroxene appears after $\sim 55$ to $65 \%$. 


\section{METHODS}

\section{Calculation of the bulk composition of the Hess Deep Rift crust}

Calculation of the bulk composition of the crust requires knowledge of the compositions and relative mass fractions of the crustal lithologies. We divide the crust into three sections: (i) the upper crust (lavas and dikes), (ii) shallow-level gabbros and (iii) deep-level gabbros. Seismic velocity-depth models for undisrupted EPR crust north of the HDR indicate a crustal thicknesses of $\sim 5.6 \mathrm{~km}$ (G. Christeson, pers. comm., 2013). Field relationships constrain the thickness of the upper crust to be $\sim 1.25 \pm 0.25 \mathrm{~km}$ (1 s.d. $)^{13}$, thus the subjacent plutonic sequence is 4.1 to $4.6 \mathrm{~km}$ thick. The volumes of the upper crust and plutonic sequence were converted to mass fractions on the basis of their density differences.

The composition of the upper crust is based on an extensive sample suite collected by submersible along vertical transects through the lava and dike sections of the northern escarpment of the HDR between $101^{\circ} 13.5^{\prime}$ to $101^{\circ} 28.5^{\prime}$ (Fig. 1b). This representative dataset includes whole-rock lava and dike $(n=157)^{30}$ and glass $(n=18)^{30,34}$ compositions. A series of test calculations were performed to assess how using either just the glasses or an average of the glass and whole-rock data impact the resulting bulk-crustal composition; minimal difference in bulk crust composition was found and thus, the mean of the two datasets was used to define the bulk-composition of the upper crust and its uncertainty. The bulk crust modeling assumes the upper crust comprises $\sim 22.5 \pm 4.5 \%$ ( 1 s.d.) of the total crustal thickness.

The shallow-level gabbro compositions are also based on an extensive sample suite, collected by submersible along the northern escarpment where the upper $1 \mathrm{~km}$ of 
the plutonic section is well-exposed subjacent to the sheeted dike complex, across a horizontal distance of $3 \mathrm{~km}^{13}$, ODP Site 894 which recovered a 150-m-long section from the upper $1 \mathrm{~km}$ of the plutonic sequence ${ }^{15}$, and samples collected by submersible from the western end of the intrarift ridge in the vicinity of ODP Site $894^{11,12}$. The mean composition of the samples from the northern escarpment $(n=56)^{35,36}$, ODP Site 894 $(n=76)^{15,37}$ and the western end of the intrarift ridge $(n=7)^{38}$ was used to define the bulk composition of the shallow-gabbros and its uncertainty. The proportion of the shallowlevel gabbros in the plutonic section is estimated using field relationships from the HDR (see above) and the Oman ophiolite ${ }^{39}$, which show them to comprise $>20-25 \%$ and $20-$ $50 \%$ of the plutonic section, respectively. The bulk crust modeling assumes that the shallow-level gabbros comprise $\sim 32.5 \pm 7.5 \%$ ( 1 s.d.) of the plutonic sequence.

The lower-level gabbro compositions are calculated from the Site U1415 samples, using the compositions of the layered gabbro series $(n=28)$ and troctolite series $(n=15)$. The proportions of the layered gabbro and troctolite series are approximately equal at IODP Holes U1415J and U1415P (the two >100 m deep drill holes), thus we model their relative proportions when calculating the bulk crustal composition and its uncertainty as $50 \pm 20 \%$

The mean compositions of the different sections of the crust calculated as explained above are given in Extended Data Table 1, along with the calculated bulk crustal and bulk plutonic sequence compositions. The uncertainties on the mass fractions of each portion of the crust, along with the uncertainty in their average compositions, was propagated into the uncertainty on the bulk crustal composition using a Monte Carlo error propagation assuming all errors are Gaussian. 


\section{Modeling Melt Differentiation}

A series of models was run to investigate whether differentiation of a parental melt with the composition of the bulk crust would produce cumulates and residual melts of similar composition to the observed plutonics and upper crustal rocks at the HDR. Both the MELTS ${ }^{22}$ and PETROLOG ${ }^{23}$ models were used to test how sensitive the results are to the model calibration. The models all assumed perfect fractional crystallization at 1 kbar and oxygen fugacities between the quartz-magnetite-fayalite (QMF) buffer and one $\log$ unit below this buffer. While perfect fractional crystallization is unlikely in oceanic crust (see, for example, ref. 9 and references therein), comparison of these trends with observed compositions from the HDR provides a first-order test of whether the calculated bulk crust composition is an appropriate parental melt composition. While the model used has a small effect on the result, all models are broadly consistent in predicting a liquidus temperature of $\sim 1300^{\circ} \mathrm{C}$, a crystallization sequence of olivine $=>$ olivine + plagioclase $=>$ olivine + plagioclase + clinopyroxene, and that orthopyroxene is not saturated until after a substantial interval of cotectic olivine + plagioclase + clinopyroxene crystallization. The PETROLOG models used the model of Kress and Carmichael ${ }^{40}$ to divide $\mathrm{Fe}$ into $\mathrm{FeO}$ and $\mathrm{Fe}_{2} \mathrm{O}_{3}$ based on the defined $f \mathrm{O}_{2}$, and various combinations of mineral models as follows: olivine: Ford et al. ${ }^{41}$ and Danyushevsky ${ }^{42}$; plagioclase: Langmuir et al. ${ }^{27}$ and Danyushevsky ${ }^{42}$; clinopyroxene: Langmuir et al. ${ }^{27}$ and Danyushevsky $^{42}$ and orthopyroxene: Beattie ${ }^{43}$ and Ariskin et al. ${ }^{44}$. The model crystallization trends shown in Fig. 3 outline the compositional range for the melt and instantaneous cumulates with progressive fractional crystallization using these mineral models in various combinations. 


\section{References:}

Nilsson, K., Oxidation state, sulfur speciation, and sulfur concentration in basaltic magmas: examples from Hess Deep and the Lau Basin, PhD thesis, Scripps Institution of Oceanography, University of California (1993).

Hanna, H.D., Geochemical variations in basaltic glasses from an incipient rift and upper level gabbros from Hess Deep, Eastern Equatorial Pacific, MSc thesis, Duke University, 94 p (2004). Natland, J.H. \& Dick, H.J.B., Paired melt lenses at the East Pacific Rise and the pattern of melt flow through the gabbroic layer at a fast-spreading ridge. Lithos 112 (1-2), 73-86 (2009). Pedersen, R.B., Malpas, J., \& Falloon, T., Petrology and geochemistry of gabbroic and related rocks from Site 894, Hess Deep in Proc. ODP, Sci. Results 147, edited by C. Mével, K.M. Gillis, J. Allen, \& P. Meyer, pp. 3-19 (Ocean Drilling Program, College Station, TX, 1996). Blum, N., Structure and composition of oceanic crust and upper mantle exposed in Hess Deep of the Galapagos microplate (equatorial east Pacific), $\mathrm{PhD}$ thesis, University Karlsruhe (1991). Nicolas, A., Boudier, F., \& Ildefonse, B., Variable crustal thickness in the Oman ophiolite: Implication for oceanic crust. J. Geophys. Res. 101 (B8), 17,941917,950 (1996). Kress, V.C. \& Carmichael, I.S.E., Stoichiometry of iron oxidation reaction in silicate melts. Am. Min. 73, 1267-1274 (1988). 
41 Ford, C.E., Russell, D.G., Craven, J.A., \& Fisk, M.R., Olivine-liquid equilibria: temperature, pressure and composition dependence of the crystal/liquid cation paritition coefficients for $\mathrm{Mg}, \mathrm{Fe}^{2+}$, Ca and Mn. J. Petrol. 24 (3), 256-265 (1983).

42 Danyushevsky, L.V., The effect of small amounts of $\mathrm{H}_{2} \mathrm{O}$ on crystallisation of mid-ocean ridge and backarc basin magmas. J. Volcan. Geotherm. Res. 110, $265-$ $280(2001)$.

43 Beattie, P., Olivine-melt and orthopyroxene-melt equilibria. Contrib. Mineral. Petrol. 115, 103-111 (1993).

44 Ariskin, A.A., Frenkel, M.Y., Barmina, G.S., \& Nielsen, R.L., COMAGMAT - A fortran program to model magma differentiation processes. Comp. Geosci. 19 (8), 1155-1170 (1993).

45 Ferrini, V.L. et al., Evidence of mass failure in the Hess Deep Rift from multiresolutional bathymetry data. Mar. Geol. 339, 13-21 (2013). 


\section{Extended Data Captions}

\section{Extend Data Figure 1. Summary lithostratigraphic columns of the gabbroic rocks} recovered at IODP Holes. a, U1415I, b, U1415J, and c, U1415P. Columns show recovery, lithological units, major rock types, dip of magmatic foliations and wellconstrained magnetic remanence inclination values (mean and 1 s.d. listed). Lithological units were identified based on similarities in rock types, magmatic textures and foliations. Paleomagnetic remanence directions and the dip of the magmatic foliations and layers (not shown) for Units II and III in Holes U1415J and $\mathrm{U} 1415 \mathrm{P}$ are most easily interpreted as blocks that were rotated relative to each other, most likely formed by slumping. G Core = ghost core, which are intervals drilled during hole cleaning operations. d, Map showing the relative locations of Holes U1415I, U1415J, and U1415P; microbathymetry data from [45]. * Unit II = Layered Gabbro Series.

Extended Data Figure 2. Core images showing examples of simple, centimeter-scale modal layering and a moderate to strong magmatic foliation. a, 345-U1415J5R-2, Piece 1, 2.0-17.5 cm. b, 345-U1415J-8R-2, Piece 9, 105.5-121.0 cm.

Extended Data Table 1. Bulk compositions of crustal sections used to calculate the bulk crust composition and the bulk composition of the HDR crust and plutonic section.

\section{Footnotes for Extended Data Table 1:}

Abbreviations: $\mathrm{FeO}^{\mathrm{T}}=$ all $\mathrm{Fe}$ as $\mathrm{FeO}$; s.e.m. $=$ standard error on the mean; s.d. $=$ standard deviation.

$$
* \mathrm{Mg} \#=\mathrm{Mg} /\left(\mathrm{Mg}+\mathrm{Fe}^{\text {Total }}\right) \text { in cations. }
$$


† Includes data for IODP Holes U1415I, U1415J, and U1415P. 


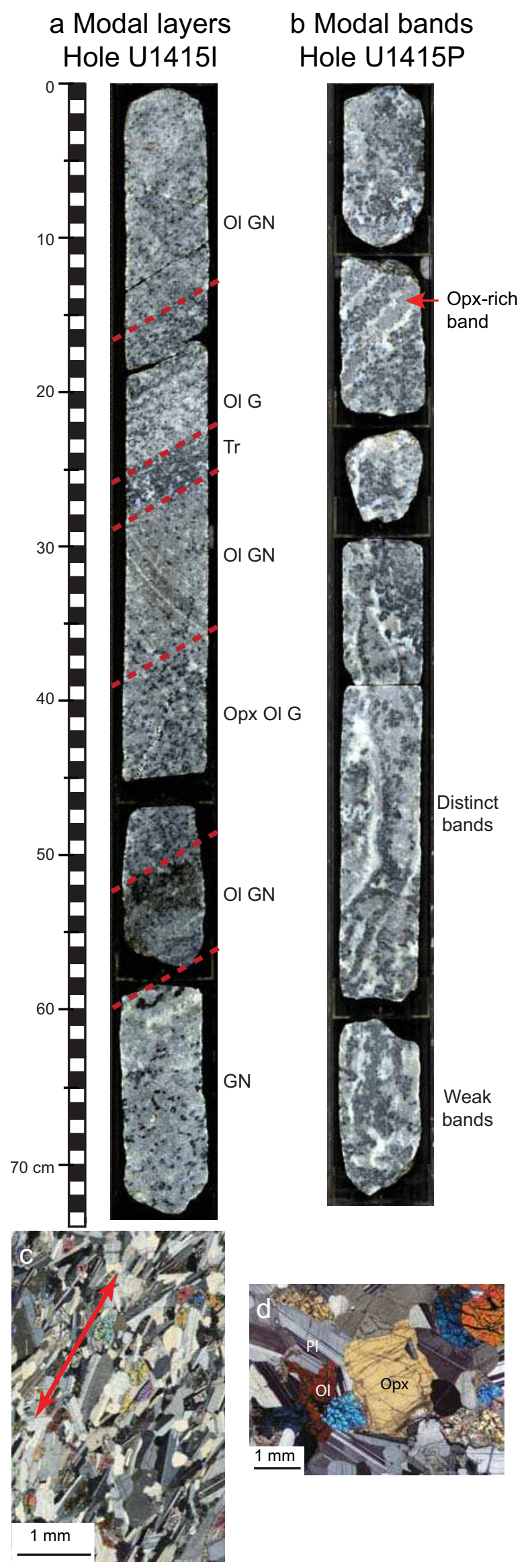

Figure 2. Gillis et al 


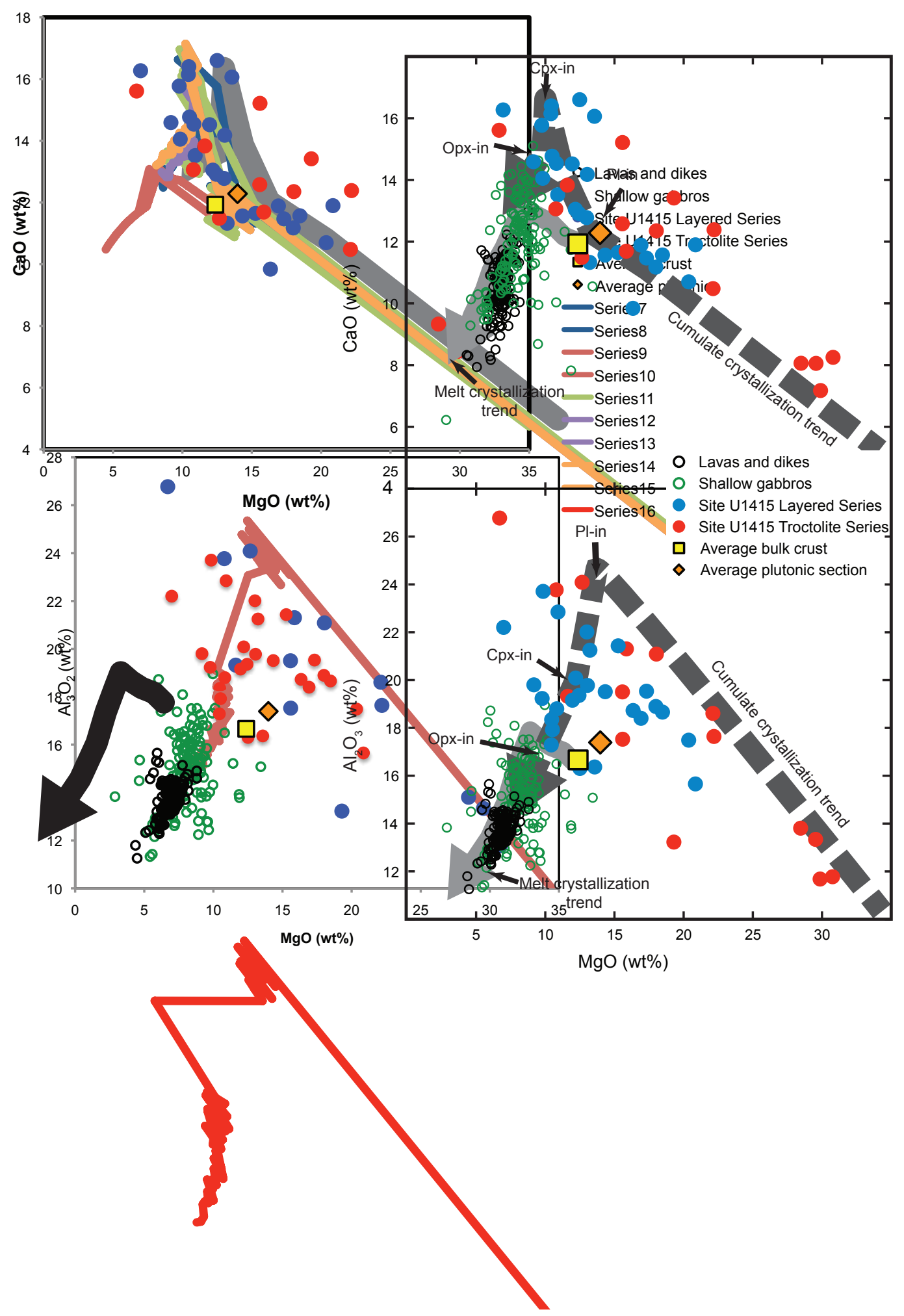

Figure 3 Gillis et al 
a Hole U1415

Cores \& Units Rock types \& Dip of magmatic

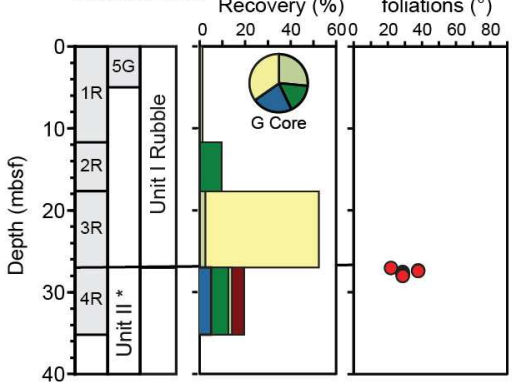

Rock types

$\square$ Troctolite

Oikocryst-bearing Troctolite

웜 Opx-bearing Olivine Gabbro

Olivine Gabbro

$\square$ Gabbro

Oikocryst Gabb

$\square$ Gabbronor

$\square$ others

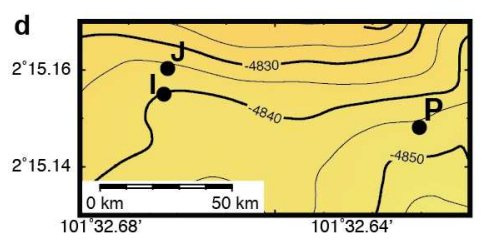

\section{b Hole U1415J}

c Hole U1415P

Cores \& Units Rock types \& Dip of magmatic Magnetic remanence Cores \& Units Rock types \& Dip of magmatic Magnetic remanence

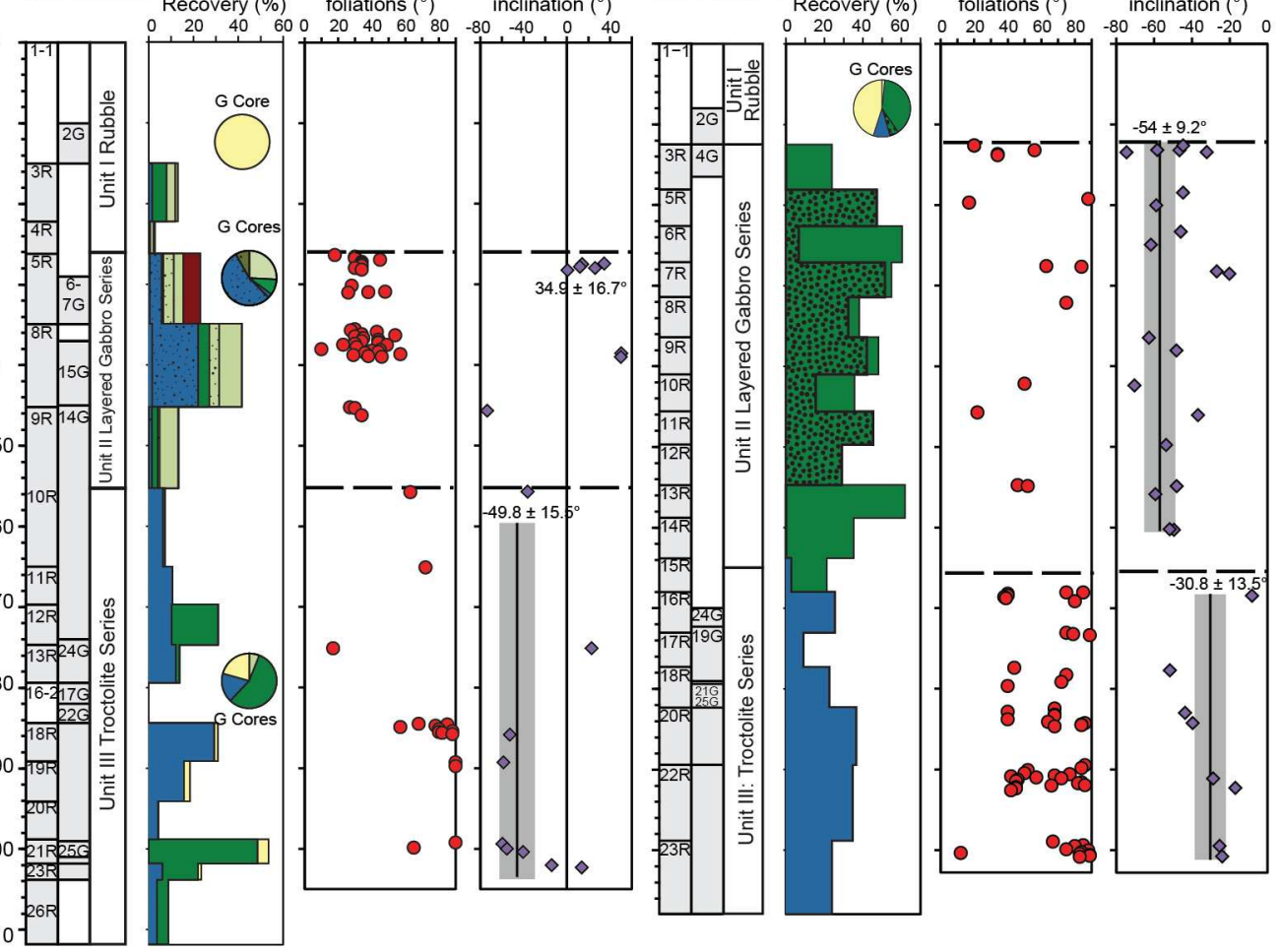

Extended Data Figure 1. 
a

\section{Troctolite
O-bearing
Gaboronorile}

Troctolite

Or-bearing

Gabbro b
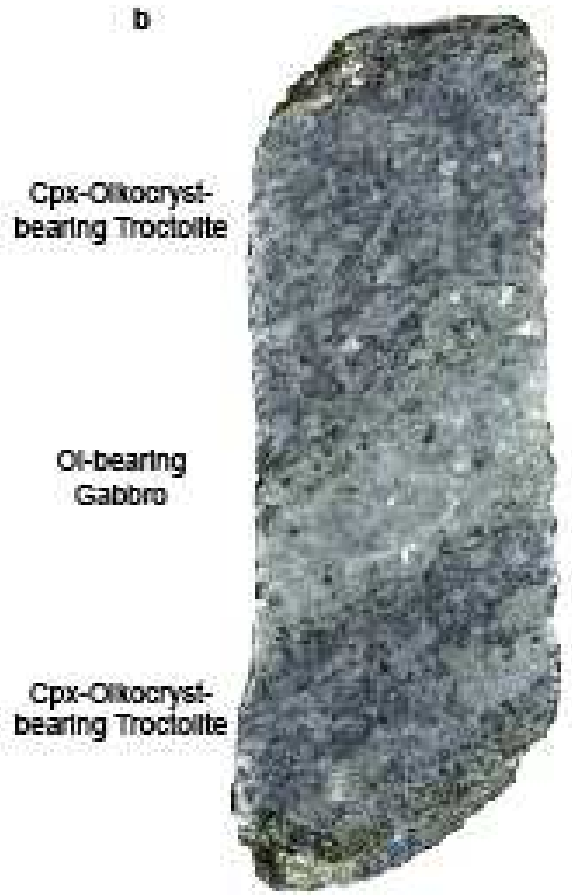

$20 \mathrm{~mm}$

Cpx-Orkocrystbearing Trociollte
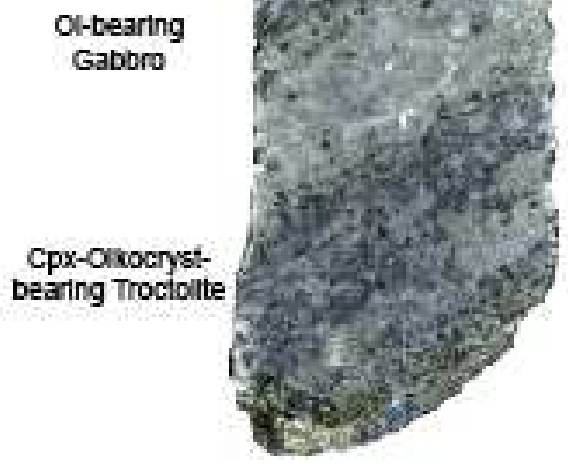


\begin{tabular}{|c|c|c|c|c|c|c|c|c|c|c|c|c|c|}
\hline & & $\mathrm{SiO}_{2}$ & $\mathrm{TiO}_{2}$ & $\mathrm{Al}_{2} \mathrm{O}_{3}$ & $\mathrm{FeO}^{\mathrm{T}}$ & $\mathrm{MnO}$ & $\mathrm{MgO}$ & $\mathrm{CaO}$ & $\mathrm{Na}_{2} \mathrm{O}$ & $\mathrm{K}_{2} \mathrm{O}$ & Total & ${\mathrm{Mg} \#{ }^{*}}$ & $\mathrm{n}$ \\
\hline Upper & mean & 50.64 & 2.12 & 13.75 & 11.79 & 0.21 & 6.83 & 10.57 & 2.77 & 0.13 & 99.87 & 50.2 & 175 \\
\hline crust & s.e.m & 0.05 & 0.03 & 0.06 & 0.12 & 0.00 & 0.05 & 0.07 & 0.02 & 0.01 & 0.05 & 0.00 & \\
\hline Shallow & mean & 51.22 & 1.15 & 15.05 & 9.09 & 0.17 & 8.09 & 12.02 & 2.41 & 0.05 & 99.32 & 61.8 & 139 \\
\hline gabbros & s.e.m. & 0.15 & 0.09 & 0.13 & 0.22 & 0.00 & 0.12 & 0.13 & 0.04 & 0.00 & 0.07 & 0.01 & \\
\hline \multicolumn{14}{|l|}{ Lower gabbros $^{\dagger}$} \\
\hline Site U1415 & mean & 47.22 & 0.16 & 19.50 & 4.95 & 0.09 & 13.40 & 13.39 & 1.46 & 0.10 & 100.78 & 82.6 & 28 \\
\hline Layered series & s.e.m. & 0.33 & 0.01 & 0.40 & 0.20 & 0.00 & 0.66 & 0.37 & 0.07 & 0.01 & 0.18 & 0.01 & \\
\hline Site U1415 & mean & 44.56 & 0.08 & 18.23 & 5.45 & 0.09 & 19.27 & 11.58 & 0.85 & 0.13 & 100.83 & 85.7 & 15 \\
\hline Troctolite series & s.e.m. & 0.47 & 0.02 & 1.31 & 0.41 & 0.01 & 2.09 & 0.69 & 0.19 & 0.02 & 0.32 & 0.01 & \\
\hline Bulk crust & & 48.32 & 0.83 & 16.71 & 7.66 & 0.14 & 12.12 & 11.95 & 1.83 & 0.11 & 99.73 & 73.8 & \\
\hline composition & s.d. & 0.51 & 0.10 & 0.50 & 0.37 & 0.01 & 1.04 & 0.31 & 0.13 & 0.01 & 0.80 & 2.2 & \\
\hline Plutonic section & & 47.65 & 0.46 & 17.57 & 6.47 & 0.12 & 13.66 & 12.35 & 1.56 & 0.10 & 100.30 & 79.0 & \\
\hline bulk composition & s.d. & 0.63 & 0.08 & 0.60 & 0.36 & 0.01 & 1.28 & 0.39 & 0.15 & 0.01 & 1.03 & 0.02 & \\
\hline
\end{tabular}

